\title{
PROBLEMS AND PROSPECTS OF INFORMATION TECHNOLOGY APPLICATION TO DEVELOPMENT OF TRANSPORT LOGISTICS FOR THE MOSUL REGION
}

\author{
A V. Panyukov ${ }^{1}$, paniukovav@susu.ru, \\ Kh. Z. Chaloob ${ }^{1}$, khalid.e@mail.ru. \\ ${ }^{1}$ South Ural State University, Chelyabinsk, Russian Federation.
}

For searching alternative ways to develop the city of Mosul, it is reasonable to take on the basis the economic and geographical position of the region. Geographical location is a border area located in the triangle of the border between Iraq and Turkey and Syria. Mosul city has sufficient potential to occupy its place at transit of goods from Turkey to Iraq. Transit is one of the promising trends for the growth of the economy as a border city and for the country as a whole. The main reasons for the opening of this line is (1) the geographical location of the city; (2) the high cost of transporting goods to the city from other areas; (3) providing of infrastructure development; (4) problems with tracking of goods, loss of goods; (5) lack of trust from intermediaries, blackout of cargo transport system. To Increase quality of logistics allows the introduction of modern information technologies, adapted to the specific characteristics of a given region. To model the rotation of interregional trade the software project is proposed. Project is based on multivariate model of international trade using the gravity model of transport costs. The functional requirements and capabilities of the program are displayed. The introduction of this program into the work of the Mosul City institutions is aimed at developing foreign trade, improving transport infrastructure and assisting decision-making not only at the individual institution level but also at the regional development policy level in the region. This contributions to the sustainable development of the region and thus partnerships new partners and investors.

Keywords: information technologies; mathematical modelling; regional economics; transport logistics.

\section{Introduction}

Today, the economic structure of many parts of Iraq is uncompetitive, and the socioeconomic situation of some of them is in a crisis. This is largely due to the dependence of the regional economy on the former sectors of the economy (textiles, leather, ferrous metals, coal, vegetable oils, etc.). Today the search for alternative ways of development of these areas is an actual problem. Their presence is a factor contributing to the imbalance of regional development.

One of these regions is Mosul: the per capita level here is not the same as the average for Iraq, as for northern Iraq. In addition, there is a relatively high degree of dependence of the regional economy on raw materials, which can not be as useful in the social and economic situation in the region.

Increase the quality of logistics service allows the introduction of modern information technologies, adapted to the specific features of a particular region [1]. At present, foreign programs are represented on the market, for example, Shipnet [5], but they do not take into account national peculiarities, and therefore can be used only in limited areas of accounting [6]. The Iraq market mainly has products for warehouse accounting [8], and transport logistics enterprises are not provided with programs designed specifically for 
them. For example, 1C [7] needs to be adjusted to solve logistical problems, and this option does not guarantee maximum visibility of expenses and correctness of their display in managerial accounting with breakdown, for example, along routes.

The problems outlined above show the relevance of the problem of developing software for modeling interregional trade. We will show that the multifactor model of international trade of $\mathrm{V}$. Leontiev with the use of a gravitational model for transport costs can be taken as a basis $[2,4]$, since they have a significant effect on trade flows.

\section{Problem Definition}

Let $r \in\{1,2, \ldots, n\}$ be a possible product, $k \in\{1,2, \ldots, K\}$ be a form of the transport, $i, j \in\{1,2, \ldots, m\}$ be possible regions. The gravitational model of transportation costs has the form $\hat{v}_{i j}^{r k}=\exp \left(\hat{d}^{r k} T_{i j}\right)$, where $\hat{v}_{i j}^{r}$ is the a priori defined of product $r$ flow from region $i$ to region $j, T_{i j}$ is the estimate of the geographical distance between regions $i$ and $j, \hat{d}^{r k}$ is the parameters responsible for the sensitivity of the flow to the distance for the given product and the type $r$ of transport $k$ used for it transportation.

At the same time, it is possible that information on certain groups of goods may not be available. In this case, the approach of modeling the transport flows in the communication network is used, which corresponds to the principle of the most probable value of the flow distribution [3]. Adapting this approach to the model of interregional trade flows leads to the need to minimize the nonlinear function

$$
\min _{x}\left[\sum_{(i, j) \in J^{2} \backslash \operatorname{diag}\left(J^{2}\right)} \sum_{r=1}^{n} \sum_{k=1}^{K}\left(x_{i j}^{r k} \ln \left(\frac{\hat{v}_{i j}^{r k}}{x_{i j}^{r k}}\right)\right)\right],
$$

here $x_{i j}^{r k}$ is the unknown quantity of product of type $r$ delivered from region $i$ to region $j$ by a transport of the form $k, \hat{v}_{i j}^{r}$ is the a priori defined product flow from region $i$ to region $j$.

At the same time, import/export restrictions must be met

$$
\begin{aligned}
& \sum_{k=1}^{K} \sum_{i=1}^{m} x_{i j}^{r k} \geq \sum_{k=1}^{K} \sum_{i=1}^{m} \hat{v}_{i j}^{r k}=V_{j}^{r}, \quad j=1,2, \ldots, m, \quad r=1,2, \ldots, n, \\
& \sum_{k=1}^{K} \sum_{j=1}^{m} x_{i j}^{r k} \geq \sum_{k=1}^{K} \sum_{j=1}^{m} \hat{v}_{i j}^{r k}=W_{i}^{r}, \quad i=1,2, \ldots, m, \quad r=1,2, \ldots, n, \\
& x_{i j}^{r k} \geq \varepsilon>0, \quad i, j=1, \ldots, m, \quad r=1,2, \ldots, n, \quad k=1,2, \ldots, K .
\end{aligned}
$$

Restrictions are in the form of inequalities, since there may be trade flows to other regions that are not considered in the model.

The proposed model allows both transit flows and redistribution of flows by different modes of transport.

\section{Main Result}

Let's consider in more detail the implementation and commercialization of software using the canvas of its business model. For the implementation of the software and 
hardware service it is possible to use a supercomputer [2,3]. The given program is intended for experts of the organizations of various patterns of ownership who face a problem of planning and optimization of goods flow.

The software is aimed at modeling multimodal and multi-nomenclature flows. For example, with the help of it, a transport balance can be found for cargo transportation in the region. Moreover, the work of the software involves the use of cloud services, which makes almost any system suitable for the installation and use of the product. Accordingly, this determines the channels for implementing the software.

The implementation of the software is based on the principle of Freemium, i.e. use of the software product for modeling own goods flows is free, but the amount of data storage and the ability to view information on other goods flows is limited. This principle will attract a wide range of users, receive feedback, assess the relevance of service in the market and identify organizations that are willing to pay for a service with improved qualities. Since customers are interested in the service, this software greatly facilitates the work of planning and optimization specialists, analytical departments, etc., as it frees them from the labor-intensive modeling process, accordingly, the working time is released, which can be spent on the solution of other problems.

Modeling of cargo flows in real time requires a large amount of computing resources, so for the modeling unit requires a high-performance computing platform. Also important are the statistical data on imports, exports, distance between transport nodes.

The most complete data at first can be provided only by state bodies. In the future, the software itself can serve as a collection of data, because for the modeling of flows users will need to enter their data, which will be stored on the cloud platform. This will greatly facilitate the accounting and control of trade flows, duties and taxes, moreover, with widespread implementation will help reduce the shadow sector.

This project is only one of the steps in the complex solution of logistical problems in the Mosul region, since other projects and other transport logistics tasks are planned to be implemented on the basis of this software, work on them is already being conducted at the Department of Mathematical and Computer Modeling of the SUSU. Also at the disposal of the university is a high-performance computing and cloud platform, on the basis of which the project is planned to be implemented. The market analysis revealed the following software requirements:

(1) the possibility of accounting for export and import flows outside the system of the region in question;

(2) the ability to take into account multi-nomenclature and multimodal transport;

(3) the ability to simulate in real time;

(4) presence of an interactive modeling system with visualization tools in a user-friendly form.

On the basis of market analysis, risks were identified, which are primarily associated with the use of cloud technology. To get rid of mistrust will be possible with the help of information work and customer support, quality service when using software.

Thus, the introduction of this software into the work of the enterprises of the Mosul region is aimed at developing foreign trade, improving the transport infrastructure, helping 
to make decisions not only at the level of an individual enterprise, but also at the level of the regional development policy of the region. This contributes to the sustainable development of the region, and, accordingly, the attraction of new partners and investors.

The work was supported by Act 211 Government of the Russian Federation, contract No. 02.A03.21.0011.

\section{References}

1. Goldsby T.J., Tyengar D., Rao S. The Critical Role of Transportation in Business and the Economy. Definitive Guide to Transportation. The: Principles, Strategies, and Decisions for the Effective Flow of Goods and Services. Indianapolis, Indiana, Pearson FT Press, 2014, available at: http://www.informit.com/articles/article.aspx?p=2171313 (accessed on March 09, 2018).

2. Panyukov A.V., Pivovarova Yu.V. Development of Transport Logistics in the Chelyabinsk Region: Problems and and the Prospects of Using Information Technologies. Bulletin of the South Ural State University. Series: Economics and Management, 2016, vol. 11, no. 1, pp. 7-11. (in Russian). doi: 10.14529/em170101.

3. Panyukov A.V., Telegin V.A Software Engineering of the Flow Algorithms. Bulletin of the South Ural State University. Series: Mathematical Modelling, Programming and Computer Software, 2008, no. 27 (127), issue 2, pp. 78-99. (in Russian).

4. Velichko A.S., Gribova V.V., Fedorishchev L.A. Cloud Service for Interactive Simulation of Interregional Trade. Modeling and Analysis of Information Systems, 2016, vol. 23, no. 4, pp. 412-426. (in Russian). doi: 10.18255/1818-1015-2016-4-412-426.

5. SHIPNET, available at: http://www.shipnet.no/Home (accessed on March 09, 2018).

6. Hildager C. ShipNet: CEO's Keynote Speech. ISS Reporter, 2014, issue 32, pp. 12-14.

7. $1 C$ COMPANY, available at: http://1c.ru/eng/ (accessed on March 09, 2018).

8. International LPI Global Ranking, available at:

http://lpi.worldbank.org/international/global (accessed on March 09, 2018).

Anatoly V. Panyukov, DSc (Math), Professor, Department of Mathematical and Computer Modeling, South Ural State University (Chelyabinsk, Russian Federation), paniukovav@susu.ru.

Khalid Z. Chaloob, Postgraduate Student, Department of Mathematical and Computer Modeling, South Ural State University (Chelyabinsk, Russian Federation), khalid.e@mail.ru.

Received March 9, 2018. 


\title{
ПРОБЛЕМЫ И ПЕРСПЕКТИВЫ ПРИМЕНЕНИЯ ИНФОРМАЦИОННЫХ ТЕХНОЛОГИЙ В ТРАНСПОРТНОЙ ЛОГИСТИКЕ В РАЙОНЕ МОСУЛА
}

\author{
А. В. Панюков, Х. З. Чалуб
}

\begin{abstract}
Для поиска альтернативных способов развития города Мосул разумно анализировать его экономическое и географическое положение. Географически Мосул находится в пограничной области между Ираком и Турцией и Сирией. Город Мосул обладает достаточным потенциалом для того, чтобы занять свое место при транзите товаров из Турции в Ирак. Транзит является одной из перспективных тенденций роста экономики как пограничного города и страны в целом. Основными причинами открытия этой линии являются (1) географическое расположение города; (2) высокая стоимость транспортировки товаров в город из других районов; (3) обеспечение развития инфраструктуры; (4) проблемы с отслеживанием товаров, потерей товаров; (5) отсутствие доверия со стороны посредников, теневая система грузовых перевозок. Для повышения качества логистики следует внедрять современные информационные технологии, адаптированные к конкретным характеристикам данного региона. Для моделирования ротации межрегиональной торговли предлагается программный проект. Проект основан на многомерной модели международной торговли с использованием гравитационной модели транспортных издержек. Внедрение программы в работу институтов города Мосул направлено на развитие внешней торговли, улучшение транспортной инфраструктуры и содействие принятию решений не только на уровне отдельных учреждений, но и на уровне региональной политики развития. Это вклад в устойчивое развитие региона и, таким образом, привлечение новых партнеров и инвесторов.

Ключевые слова: информачионные технологии; математическое моделирование; региональная экономика; транспортная логистика.
\end{abstract}

\section{Литература}

1. Goldsby, T.J. The Critical Role of Transportation in Business and the Economy / T.J. Goldsby, D. Tyengar, S. Rao // Definitive Guide to Transportation. The: Principles, Strategies, and Decisions for the Effective Flow of Goods and Services. - Indianapolis, Indiana: Pearson FT Press, 2014. url: http://www.informit.com/articles/article.aspx?p=2171313 (дата обращения: 09 марта 2018).

2. Панюков, А.В. Развитие транспортной логистики в Челябинской области: проблемы и перспективы применения информационных технологий /А.В. Панюков, Ю.В. Пивоварова // Вестник ЮУрГУ. Серия: Экономика и менеджмент. - 2016. T. 11, № 1. - C. 7-11.

3. Панюков, А.В. Техника программной реализации потоковых алгоритмов А.В. Панюков, В.А. Телегин // Вестник ЮУрГУ. Серия: Математическое моделирование и программирование. - 2008. - № 27 (127), вып. 2. - С. 78-99.

4. Величко, А.С. Облачный сервис для интерактивного моделирования межтерриториальной торговли / А.С. Величко, В.В. Грибова, Л.А. Федорищев // Моделирование и анализ информационных систем. - 2016. - Т. 23, № 4. - С. 412-426. 
5. SHIPNET. url: http://www.shipnet.no/Home (дата обращения: 09 марта 2018).

6. Hildager C. ShipNet: CEO's keynote speech / C. Hildager // ISS Reporter. - 2014.-Issue $32 .-$ P. $12-14$.

7. Фирма «1C». url: http://1c.ru/ (дата обращения: 09 марта 2018).

8. International LPI global ranking. url: http://lpi.worldbank.org/international/global (дата обращения: 09 марта 2018).

Панюков Анатолий Васильевич, доктор физико-математических наук, профессор, кафедра математического и компьютерного моделирования, ЮжноУральский государственный университет (г. Челябинск, Российская Федераиия), paniukovav@susu.ru.

Чалуб Халид, аспирант, кафедра математического и компьютерного моделирования, Южно-Уральский государственный университет (г. Челябинск, Российская Федераu,я),khalid.e@mail.ru.

Поступила в редакицю 9 марта 2018 г. 